\title{
Efficacy of commercially available disinfectants against human norovirus surrogates and Clostridioides difficile endospores
}

\section{Jinge Huang}

Clemson University

Geun W Park

CDC: Centers for Disease Control and Prevention

Rachael Jones

Utah State University Eastern

Angie Frazer

Clemson University

Jan Vinje

CDC: Centers for Disease Control and Prevention

Xiuping Jiang ( $\nabla$ xiuping@clemson.edu )

Clemson University https://orcid.org/0000-0003-3705-0530

\section{Research}

Keywords: Human norovirus surrogate, feline calicivirus, Tulane virus, Clostridioides difficile endospores, disinfection efficacy, hydrogen peroxide

Posted Date: September 23rd, 2021

DOI: https://doi.org/10.21203/rs.3.rs-903165/v1

License: (c) (1) This work is licensed under a Creative Commons Attribution 4.0 International License. Read Full License 


\section{Abstract \\ Background}

Routine disinfection of environmental surfaces is essential to control the spread of pathogens that cause healthcare-associated infections. The aim of this study was to determine the efficacy of a panel of disinfectants against two human norovirus surrogates [feline calicivirus (FCV) and Tulane virus (TuV)] and Clostridioides difficile endospores.

\section{Methods}

Nine products on EPA's List $\mathrm{G}$ were selected using four criteria: 1) ready-to-use, 2) nonchlorine-based active ingredient, 3) commercially available, and 4) limited known health risks. Active ingredients of the products included hydrogen peroxide $\left(\mathrm{H}_{2} \mathrm{O}_{2}\right)$, peracetic acid, quaternary ammonium compounds, or alcohols. The efficacy of the products against FCV, TuV and $C$. difficile spores was tested using the ASTM suspension test and on stainless steel coupons for 1, 5 and $10 \mathrm{~min}$ (FCV, TuV) and $10 \mathrm{~min}$ (C. difficile spores).

\section{Results}

On stainless steel carriers, seven of the nine products reduced FCV $>5.1 \log$ after 5 min of contact time and eight products after $10 \mathrm{~min}$. One product reduced TuV $>3.1 \mathrm{log}$ after 5 min while 8 products could not achieve this level of reduction even after $10 \mathrm{~min}$. Only one product achieved $>6.0$ log reduction of $C$. difficile spores after $10 \mathrm{~min}$ while other 8 products could not achieve this acceptable efficacy. The two most efficacious products contained $\mathrm{H}_{2} \mathrm{O}_{2}$ as active ingredient and resulted in $>5.1$ log reduction of FCV and $\geq 2.4$ log reduction of TuV after 5 min contact time on stainless steel carriers. However, among the five products containing $\mathrm{H}_{2} \mathrm{O}_{2}$, no strong correlation $\left(\mathrm{R}^{2}=0.25, p=0.03\right)$ between log reduction and $\mathrm{H}_{2} \mathrm{O}_{2}$ concentration was detected using the ASTM suspension test, suggesting product formulation, not active ingredient concentration, impacts efficacy.

\section{Conclusion}

A panel of nine EPA-approved disinfectants was tested against two HuNoV surrogates (FCV and TuV) and $C$. difficile endospores. The most efficacious products contained hydrogen peroxide as active ingredient. TuV was confirmed to be the more conservative surrogate for HuNoV than FCV. No strong correlation between log reduction and hydrogen peroxide concentration was detected, suggesting that product formulation has a significant impact on the efficacy of a product.

\section{Introduction}

Healthcare-associated infections (HAls) are clearly linked to high morbidity, mortality, and increased healthcare costs (1-3). For many years, reducing the number of HAls has been a top priority of public health 
agencies in the United States $(2,3)$. While progress has been made in recent years, a substantial burden from HAls still persists. Many HAls involve pathogens that are transmitted person-to-person via direct or indirect contact (4-6) via a contaminated intermediate object (or fomite), such as an environmental surface (7).

Disinfectants are an essential tool for efficient environmental cleaning and several hundred disinfectants with an array of active ingredients and formulations are commercially available. The most common active ingredients include chlorine, quaternary ammonium chemicals (QACs), alcohols, and peroxides (8), with each having limitations. For example, chlorine-based disinfectants are highly efficacious against bacteria and viruses but because they are strong oxidizers, they can damage surfaces when used at high concentrations or after prolonged use $(9,10)$. QACs and alcohols are less likely to damage surfaces but have weak activity against non-enveloped viruses [e.g., human norovirus (HuNoV)] and bacterial spores (e.g., Clostridioides difficile) (8). Peroxides, including accelerated hydrogen peroxide $\left(\mathrm{H}_{2} \mathrm{O}_{2}\right)$, can denature viral proteins, but efficacy data from published studies are limited (8).

To help decide which disinfectant to use, the U.S. Environmental Protection Agency (EPA) maintains 15 individual lists of antimicrobial products registered as effective against common pathogens (11). Two of these lists specifically address pathogens known to cause HAls. List $\mathrm{G}$ currently includes 148 products effective against HuNoV and List $K$ includes 64 products effective against $C$. difficile spores $(12,13)$. To be EPA-registered as efficacious against HuNoV, products must achieve at least a 4-log reduction of feline calicivirus (FCV), a surrogate for HuNoV within contact time of $10 \mathrm{~min}$ (14), as at present HuNoV is difficult to culture in vitro. To be registered as efficacious against $C$. difficile, products must achieve at least a 6-log reduction of $C$. difficile spores within 10 min (15). Other HuNoV surrogates have been reported including murine norovirus, sapovirus, and Tulane virus (TuV), but none perfectly mimics HuNoV $(16,17)$. TuV, not required to be used to test product efficacy, is more resistant to disinfectants than other norovirus surrogates, including FCV (17). Testing product efficacy against TuV in addition to FCV might yield more conservative estimates of disinfectant efficacy against HuNoV.

To determine efficacy, the EPA requires glass carrier tests be used $(18,19)$, however, results based on the use of glass coupons might not translate well to other materials (e.g., brushed stainless steel and plastics). An alternative testing method is ASTM E2197-17 (20), which uses brushed stainless steel coupons to determine efficacy. Brushed stainless steel is widely used to construct high-contact surfaces in healthcare settings, such as doorknobs, bathroom handrails and bed frames $(21,22)$. At present, no published data are available in which these two methods have been compared in interpreting the efficacy of disinfectants.

The aim of this study was to determine the efficacy of a panel of EPA-approved disinfectants against two HuNoV surrogate viruses (FCV and TuV) and $C$. difficile endospores, using the ASTM methods, which might yield more conservative estimates of disinfectant efficacy. These findings can inform modifications of standard testing methods on hard non-porous surfaces used to evaluate broad-spectrum disinfectants.

\section{Materials And Methods}

\section{Virus propagation and assays}


Crandell-Rees Feline Kidney (CRFK) cells (ATCC CCL-94) were cultured in Eagle's modified essential medium (MEM; Gibco Life Technologies, NY, USA) containing 5\% low-endotoxin heat-inactivated fetal bovine serum (FBS) (Seradigm, VWR International, Radnor, PA, USA), 100 U/L penicillin (HyClone, GE, MA, USA), and 100 $\mathrm{mg} / \mathrm{L}$ streptomycin (HyClone). Ninety percent confluent monolayers of CRFK cells were infected with FCV strain F9 (ATCC VR-782; American Type Culture Collection, VA, USA) at a multiplicity of infection (MOI) of 0.01 and held at $37^{\circ} \mathrm{C}$ for 2 days. FCV was then harvested from cell lysates by three freeze-thaw cycles followed by centrifugation for $10 \mathrm{~min}$ at $5,000 \times \mathrm{g}$ and $4^{\circ} \mathrm{C}$. FCV stocks at ca. $10^{8} \mathrm{PFU} / \mathrm{mL}$ were aliquoted and stored at $-80^{\circ} \mathrm{C}$. Infectious FCV was quantified by standard plaque assay as previously described (23). To test for cell line permissiveness and contamination, FCV and PBS served as a positive and negative control, respectively. CRFK cells were passaged less than 30 times.

LLC-MK2 cells (ATCC CCL-7) were cultured in Opti-MEM I reduced serum medium (Gibco Life Technologies) supplemented with $2 \%$ low-endotoxin heat-inactivated FBS, $100 \mathrm{U} / \mathrm{L}$ penicillin, and $100 \mathrm{mg} / \mathrm{L}$ streptomycin. Ninety percent confluent monolayers of LLC-MK2 cells were infected with TuV, provided by Dr. Jason Jiang (Cincinnati Children's Hospital, $\mathrm{OH}, \mathrm{USA}$ ), at an MOI of 0.1 and held at $37^{\circ} \mathrm{C}$ for 2 days. TuV was harvested from cell lysates similar as for FCV. Infectious TuV titer was quantified by the median tissue culture infectious dose $\left(\mathrm{TCID}_{50}\right)$ assay as described with modifications (24). Twenty microliters of serially diluted viruses were added in each quantification well per column and 8 wells used for each dilution. TuV stocks at ca. $10^{7} \mathrm{TCID}_{50} / \mathrm{mL}$ were aliquoted and stored at $-80^{\circ} \mathrm{C}$. LLC-MK2 cells were passaged fewer than 30 times.

\section{Preparation and purification of C. difficile spores}

C. difficile (ATCC 43593) was cultured on modified brain heart infusion agar plates containing $5 \mathrm{~g} / \mathrm{L}$ yeast extract, $1 \mathrm{~g} / \mathrm{L}$ cysteine and $1 \mathrm{~g} / \mathrm{L}$ sodium taurocholate (BHIA/YE/CYS/T) and anaerobically incubated at $37^{\circ} \mathrm{C}$ for 7 days. All plates were sealed with parafilm (Pechiney, IL, USA) and incubated at ambient conditions for an additional 7 days. The agar plate was flooded with $5 \mathrm{~mL}$ of $0.01 \mathrm{M}$ PBS with $0.1 \%$ Tween-80 and the colony mass was scraped from the agar plates using sterile cotton swabs. The cell suspension was washed 5 times by ice-cold sterile deionized ( $\mathrm{DI}$ ) water followed by centrifugation at $7,000 \times \mathrm{g}$ for $5 \mathrm{~min}$ at $4^{\circ} \mathrm{C}$. Vegetative cells of $C$. difficile were removed by gradient centrifugation in $50 \%(w / v)$ sucrose solution (25). The spore suspension was washed three times with sterile ice-cold water after purification. Concentration of spores was enumerated on BHIA/YE/CYS/T plates and the purity of prepared spores confirmed via spore staining. The stock culture of $C$. difficile spores at ca. $10^{8} \mathrm{CFU} / \mathrm{mL}$ was stored at $4^{\circ} \mathrm{C}$ for routine tests and at $-80^{\circ} \mathrm{C}$ for long-term storage.

\section{Candidate disinfectants}

Candidate disinfectants had to appear on List G, EPA's Registered Antimicrobial Products Effective against Norovirus ( $N=148$ ). Selection criteria included (Fig. 1A): 1) ready-to-use (RTU), 2) nonchlorine-based, 3 ) commercially available, and 4) limited known health risks (Table S1). Nine products met our criteria (Table 1). The active ingredients, claimed contact times, and pH of selected products are listed in Table 1. A sodium hypochlorite solution $(1,000 \mathrm{ppm})$ was evaluated in the carrier test as a positive control. 
Table 1

Active ingredients of selected disinfecting products and appropriate neutralizers.

\begin{tabular}{|c|c|c|c|c|c|c|}
\hline \multirow[t]{2}{*}{ Product } & \multirow[t]{2}{*}{ Active ingredient } & \multirow[t]{2}{*}{$\mathrm{pH}$} & \multirow[t]{2}{*}{$\begin{array}{l}\text { Neutralizer } \\
\text { (concentration) }\end{array}$} & \multicolumn{2}{|c|}{$\begin{array}{l}\text { Label contact } \\
\text { time }(\min )^{a}\end{array}$} & \multirow{2}{*}{$\begin{array}{l}\text { Cytotoxicity/CPE } \\
\text { after } \\
\text { neutralization }\end{array}$} \\
\hline & & & & FCV & $\begin{array}{l}\text { C. } \\
\text { difficile }\end{array}$ & \\
\hline A & $0.5 \%$ hydrogen peroxide & 2.64 & $\begin{array}{l}\text { catalase }(1300 \\
\mathrm{U} / \mathrm{mL})\end{array}$ & 1 & NA & $-b$ \\
\hline B & $0.88 \%$ hydrogen peroxide & 2.85 & $\begin{array}{l}\text { catalase }(1300 \\
\mathrm{U} / \mathrm{mL})\end{array}$ & 10 & NA & - \\
\hline C & $1.4 \%$ hydrogen peroxide & 2.38 & $\begin{array}{l}\text { catalase }(1300 \\
\mathrm{U} / \mathrm{mL})\end{array}$ & 1 & NA & - \\
\hline D & $\begin{array}{l}3.13 \% \text { hydrogen } \\
\text { peroxide/0.099\% octanoic } \\
\text { acid/ } 0.05 \% \text { peracetic acid }\end{array}$ & 2.95 & $\begin{array}{l}\text { catalase }(1300 \\
\mathrm{U} / \mathrm{mL})\end{array}$ & 4 & 10 & - \\
\hline$E$ & $\begin{array}{l}5 \% \text { hydrogen } \\
\text { peroxide } / 0.005 \% \text { silver }\end{array}$ & 3.07 & $\begin{array}{l}\text { catalase }(1300 \\
\mathrm{U} / \mathrm{mL})\end{array}$ & 10 & NA & - \\
\hline $\mathrm{F}$ & $\begin{array}{l}4.85 \% \text { citric acid } / 0.003 \% \\
\text { silver }\end{array}$ & 1.79 & FBS (5\%) & 10 & NA & - \\
\hline G & $\begin{array}{l}0.2 \% \text { chlorine } \\
\text { dioxide/ } 0.125 \% \text { alkyl } \\
\text { dimethyl benzyl } \\
\text { ammonium } \\
\text { chloride/ } 0.125 \% \text { alkyl } \\
\text { dimethyl ethylbenzyl } \\
\text { ammonium chloride }\end{array}$ & 8.68 & $\begin{array}{l}\text { FBS }(5 \%)+ \\
\text { sodium } \\
\text { thiosulfate } \\
(0.1 \%)\end{array}$ & 5 & NA & - \\
\hline $\mathrm{H}$ & $\begin{array}{l}15 \% \text { isopropanol } / 7.5 \% \\
\text { ethanol/0.76\% } \\
\text { didecyldimethylammonium } \\
\text { chloride }\end{array}$ & 12.17 & $\begin{array}{l}\text { FBS }(5 \%)+ \\
\text { sodium } \\
\text { thiosulfate } \\
(0.1 \%)\end{array}$ & 1 & NA & - \\
\hline I & $29.4 \%$ ethanol & 13.07 & FBS (5\%) & 0.5 & NA & $+^{c}$ \\
\hline \multicolumn{7}{|c|}{ a Recommended contact time against FCV listed on product labels; NA represents "not available". } \\
\hline \multicolumn{7}{|c|}{$\begin{array}{l}\text { b No cytotoxicity/CPE to both cell lines after neutralization, i.e., }<1 \text { log reduction of viruses or spores in } \\
\text { neutralization effectiveness treatments. }\end{array}$} \\
\hline
\end{tabular}

As contact times listed on product labels for HuNoV ranged from 0.5 to 10 min (Table 1), 1 min was used in suspension tests to determine efficacy against FCV, while three contact times $-1,5$ and 10 min were used in the quantitative carrier tests to identify a minimum general contact time. No products provided claims against TuV; therefore, 10 min was used in the suspension test study and the same three contact times were used in the carrier test in order to compare FCV and TuV results. Only product $\mathrm{D}$ had a claimed time for $C$. difficile spores, which was 10 min, so this contact time was used in both the suspension and the carrier test. 


\section{Cytotoxicity and neutralization tests}

Specific neutralizers (Table 1) were evaluated for each product as previously described with modifications (23). An additional "washing step" was used to eliminate all residue cytotoxicity and antimicrobial activities. Briefly, mixtures of products and neutralizers were diluted by adding $3 \mathrm{~mL}$ PBS then concentrated via centrifugation using Amicon ${ }^{\circledR}$ Ultra-4 centrifugal 30K MWCO filters (Millipore Sigma, MA, USA) at 4,000 $\times$ g, $4^{\circ} \mathrm{C}$, which was repeated 3 times to remove disinfectant residue in the mixture. Following the washing step, undiluted, $10^{-1}$ and $10^{-2}$ diluted solutions of product mixtures were assayed by plaque assay for CRFK cells and $\mathrm{TCID}_{50}$ assay for LLC-MK2 cells, as described above. Cytotoxicity against these cell lines was observed under an inverted microscope (Olympus CK2) and recorded at days 2 and 5 . To test neutralization effectiveness, $10 \mu \mathrm{L}$ of either diluted FCV (ca. $10^{4} \mathrm{PFU} / \mathrm{mL}$ ) or TuV (ca. $10^{7} \mathrm{TCID}_{50} / \mathrm{mL}$ ) stock were mixed with product-neutralizer solution and assayed as described above. As for $C$. difficile, $10 \mu \mathrm{L}$ of spores (ca. $10^{4}$ $\mathrm{CFU} / \mathrm{mL}$ ) were directly added to the product-neutralizer solution.

\section{Quantitative suspension test}

Efficacy was first tested using ASTM standard E1052-11 (26) with several modifications (Fig. 1B). Briefly, 10 $\mu \mathrm{L}$ of FCV, TuV, or $C$. difficile spores were each mixed separately with $90 \mu \mathrm{L}$ of undiluted disinfectant in a 1.5 $\mathrm{mL}$ centrifuge tube at room temperature for a designated contact time. The contact times were $1 \mathrm{~min}$ for FCV, 10 min for TuV and $10 \mathrm{~min}$ for $C$. difficile spores. PBS was used as a negative control. Mixtures were neutralized by adding $900 \mu \mathrm{L}$ of neutralizer (Table 1), then washed using Amicon ${ }^{\circledR}$ Ultra-4 centrifugal $30 \mathrm{~K}$ MWCO filters for both FCV and TuV, as described above. After removal of product residue, the retentate was collected and assayed with CRFK cells and LLC-MK2 cells for FCV and TuV, respectively (Fig. 1B). Without using centrifugal units, $C$. difficile spores were collected directly after neutralization and enumerated as described above.

\section{Quantitative carrier test}

Efficacy of the nine products was then tested using ASTM standard E2197-17 with some modifications (20). A sodium hypochlorite solution (1,000 ppm) (Clorox, CA, USA) was used as a positive control. Briefly, each coupon of brushed stainless steel (Muzeen \& Blythe Ltd., MB, Canada) disk ( $1 \mathrm{~cm}$ in diameter) placed in a 24-well plate (Corning, NY, USA) was inoculated with $10 \mu \mathrm{L}$ of one stock suspension of FCV, TuV, or $C$. difficile spores and dried for $1.5 \mathrm{~h}$ inside a biological safety cabinet at room temperature with $30-50 \%$ relative humidity. Dried disks were then incubated with $90 \mu \mathrm{L}$ of each disinfectant. After the designated contact time $(1,5$, and $10 \mathrm{~min}$ for FCV and TuV, and $10 \mathrm{~min}$ for $C$. difficile), $900 \mu \mathrm{L}$ of respective neutralizing broth (Table 1) were pipetted into each well to neutralize biocidal activity of disinfectant and to facilitate elution of virus or spores from coupons. Samples were then assayed as described above. As for $C$. difficile spores, coupons were first sonicated for $15 \mathrm{~s}$ at $40 \mathrm{kHz}$ in a sonication bath (FS110; Fisher Scientific International, PA, USA) after neutralization then pipetted up and down 10 times to remove spores from carrier coupons. Spore suspensions were collected and enumerated as described above. Neutralization verification and cytotoxicity elimination were conducted as described in the ASTM standard (20). The acceptable efficacy was a 4-log reduction of FCV and a 6-log reduction of $C$. difficile spores $(14,15)$. As TuV is not recognized by EPA as a testing agent, an acceptable efficacy of 3-log reduction of general viral surrogates was used (14). 
Inactivation kinetics of four products against $\mathrm{C}$. difficile spores

To evaluate the correlation between concentration of active ingredients and efficacy for $\mathrm{H}_{2} \mathrm{O}_{2}$-based disinfectants, inactivation kinetic parameters of four products (A, C, D, and E) that showed efficacy against both virus surrogates and $C$. difficile spores were determined using a suspension test. The D-value was calculated from the inactivation kinetic curve using the following equation:

$$
\mathrm{D}=\frac{\mathrm{t}}{\log _{10} \frac{\mathrm{N}_{0}}{\mathrm{~N}_{\mathrm{d}}}}
$$

where $\mathrm{D}$ means D-value ( $\mathrm{min}$ ) at ambient conditions, $\mathrm{N}_{0}$ indicates spore population in the positive spore control, and $\mathrm{N}_{d}$ indicates surviving spore population after an exposure time of $t(\mathrm{~min})$. To obtain values used in the model, five contact times were evaluated for each of those products. Contact times for products $A$ and D were 1, 2, 3, 4 and 5 min, while longer contact times of 5, 10, 15, 20 and 25 min were used to test products $\mathrm{C}$ and $\mathrm{E}$ for an accurate calculation.

\section{Synergistic effect of hydrogen peroxide and ferrous sulfate}

Only $\mathrm{H}_{2} \mathrm{O}_{2}$-based products presented strong antimicrobial activity against $\mathrm{FCV}$, TuV, and $\mathrm{C}$. difficile spores in either suspension or carrier test. Therefore, the efficacy of $\mathrm{H}_{2} \mathrm{O}_{2}$ (Honeywell, NC, USA) against FCV, TuV, and C. difficile spores was tested with the addition of $\mathrm{FeSO}_{4}$ to $\mathrm{H}_{2} \mathrm{O}_{2}$-based products, known as the Fenton reaction. This was done to better understand the effect of $\mathrm{H}_{2} \mathrm{O}_{2}$-based formulations against both $\mathrm{HuNoV}$ surrogates and $C$. difficile spores. $\mathrm{H}_{2} \mathrm{O}_{2}$ solutions of $0.5,1,3$ and $5 \%(\mathrm{w} / \mathrm{v})$ were prepared by diluting the concentrated $\mathrm{H}_{2} \mathrm{O}_{2}$ solution (50\%) in deionized (DI) water and the $\mathrm{pH}$ adjusted to $2.90 \pm 0.05$ with $1 \mathrm{M}$ citric acid. To determine the impact of Fenton reaction, $0.025 \%(\mathrm{w} / \mathrm{v}) \mathrm{FeSO}_{4}$ was added into $1 \%(\mathrm{w} / \mathrm{v}) \mathrm{H}_{2} \mathrm{O}_{2}$ solution compared to $0.025 \%(\mathrm{w} / \mathrm{v}) \mathrm{FeSO}_{4}$ in DI water, which was used as a negative control.

\section{Statistical analysis}

Four replicates of 10-fold serial dilutions of each product were tested in two independent experiments. Log reductions were calculated by $\log \left(N_{0} / N_{d}\right)$, where $N_{d}$ is the average from the treatment samples and $N_{0}$ is the average from each control sample. Statistical analysis was performed using a one-way multiple-comparison $t$-test to determine the relationship between contact time and log reduction. All results were expressed as mean \pm standard deviation. Statistical significance was defined as a $p$-value of $<0.01$ to establish a more conservative estimation of efficacy. Statistical analyses were conducted using GraphPad Prism 6.01 (GraphPad Software, Inc., CA, USA).

\section{Results}

\section{Quantitative suspension test}


The cytotoxicity of each product was neutralized with an active ingredient-specific neutralizer (Table 1). Although 5\% FBS initially did not neutralize product I, additional washing steps with PBS using centrifugal filters eliminated all remaining cytotoxicity (i.e., $<1$ log reduction of viruses and $C$. difficile spores).

After 1 min contact time, the four $\mathrm{H}_{2} \mathrm{O}_{2}$-based products (A-D) and one ethanol-based product (I) achieved a $5.1,4.1,5.0,>5.4$ and 5.2 log reduction of FCV, respectively, whereas the remaining four products $(E-H)$ achieved a 2.7, 2.2, 0.3 and $1.9 \mathrm{log}$ reduction of FCV, respectively (Table S2). Products A-D, H, and I achieved a 3.8, 3.4, 3.8, 3.9, 3.8 and 4.3 log reduction of TuV after 10 min contact time, respectively. Reduction of TuV by product $E$ was 0.2 logs. Only product $D$ listed a 10-min contact time against $C$. difficile spores on its label (Table 1), but products $A$ and $D$ both showed a $>6.0$ log reduction of $C$. difficile spores after 10 min, while products $\mathrm{C}$ and $\mathrm{E}$ showed a 1.4 and 1.3 log reduction, respectively. Compared to the negative control, five other products (B and $\mathrm{F}-\mathrm{I})$ did not significantly reduce $C$ difficile spores $(p \geq 0.01)$.

\section{Quantitative carrier test}

As no product achieved an acceptable efficacy against TuV after 1 min contact time (Table S3), results for 5 min (Fig. 2) were used to compare the efficacy between FCV and TuV. Seven of the 9 products and the sodium hypochlorite solution (1,000 ppm) achieved a $>5.1$ log reduction of FCV after 5 min (Fig. 2), while products $\mathrm{E}$ and $\mathrm{G}$ resulted in a 2.2- and 0.2-log reduction, respectively. Product $\mathrm{H}$ was not efficacious after a contact time of $1 \mathrm{~min}$, but was efficacious after $5 \mathrm{~min}$ (Table S3). For TuV, both sodium hypochlorite solution and product $\mathrm{D}$ showed $\mathrm{a}>3.1 \mathrm{log}$-reduction after 5 min contact time, while products $\mathrm{C}$ and $\mathrm{I}$ achieved a 2.4 and 1.9 log-reduction, respectively (Fig. 2). Only product $D$ achieved a $>6.0$-log reduction of $C$. difficile spores after $10 \mathrm{~min}$, whereas product $\mathrm{A}$ and sodium hypochlorite solution resulted in a 3.4- and 4.4-log reduction, respectively (Fig. 2).

Inactivation kinetics against $\mathrm{C}$. difficile spores in suspension

Both products $A$ and $D$ reduced $C$. difficile spores to under the detection limit (equivalent to $>6.0$ - $\log$ reduction) in 4 and 3 min, respectively (Fig. 3). Viable counts of $C$. difficile spores decreased by $0.9,1.5,2.4$, 3.7 and 5.0 logs after $5,10,15,20$ and 25 min of contact with product $C$, respectively, and 0.9, 2.1, 2.9, 3.8 and 4.7 logs reduction after $5,10,15,20$ and 25 min of contact with product $E$, respectively. As compared with other $\mathrm{H}_{2} \mathrm{O}_{2}$-based products, product $\mathrm{E}$ had a higher $\mathrm{H}_{2} \mathrm{O}_{2}$ concentration ( $5 \%$ ) but had a higher D-value (5.6 $\mathrm{min}$ ) against $C$. difficile spores as compared with $\mathrm{D}$-values of 0.7 and 0.4 for products $A$ and $\mathrm{D}$. The $\mathrm{D}$ value for product $\mathrm{C}$ was $6.2 \mathrm{~min}$.

\section{Synergistic effect of hydrogen peroxide and ferrous sulfate}

Laboratory-prepared solutions of $3 \% \mathrm{H}_{2} \mathrm{O}_{2}$ and $5 \% \mathrm{H}_{2} \mathrm{O}_{2}$ achieved a 3.9- and 4.1-log reduction of FCV after 1 min (lines in Fig. 4). The same two solutions achieved a 1.6 and 1.8 log reduction of TuV and 1.5 and 2.1 log reduction of $C$. difficile spores. The log reduction decreased for $\mathrm{FCV}$, TuV, and $C$. difficile spores $(<2.1,0.7$ and $0.3 \mathrm{log}$, respectively) at lower concentrations of $\mathrm{H}_{2} \mathrm{O}_{2}(\leq 1 \%)$. 
Product $A$, with $0.5 \% \mathrm{H}_{2} \mathrm{O}_{2}$, achieved $\geq 3$-log reduction of both viral surrogates and $C$. difficile spores, while product $\mathrm{E}$, with $5 \% \mathrm{H}_{2} \mathrm{O}_{2}$, resulted in a 2.7, 2.5 and $1.3 \mathrm{log}$ reduction of $\mathrm{FCV}$, TuV, and $C$. difficile spores, respectively. $\mathrm{H}_{2} \mathrm{O}_{2}$ was the only active ingredient in products $A, B$ and $C$. Except for product $E$, these four products showed higher antiviral activity (additional $\geq 1$.5-log reduction of FCV or TuV) than pure $\mathrm{H}_{2} \mathrm{O}_{2}$ solutions with equivalent concentrations (dots in Fig. 4). Products $A, C$, and D had stronger activity against $C$. difficile spores than pure $\mathrm{H}_{2} \mathrm{O}_{2}$ solutions. Overall, no strong correlation $\left(\mathrm{R}^{2}=0.25, p=0.03\right)$ between log reduction and $\mathrm{H}_{2} \mathrm{O}_{2}$ concentration was observed.

Ferrous sulfate at $0.025 \%$ had a minimal effect on FCV, TuV, and $C$. difficile spores with $\leq 0.2$ log reduction after 1,10 , and 10 min, respectively (Fig. 5). Addition of $0.025 \%$ ferrous sulfate improved efficacy of $1 \% \mathrm{H}_{2} \mathrm{O}_{2}$ solution against FCV, TuV, and $C$. difficile resulting in additional $1.4,0.4$ and 0.9 log reduction, respectively.

\section{Discussion}

We determined the efficacy of a panel of nine EPA-approved disinfectants against two HuNoV surrogate viruses (FCV and TuV) and $C$. difficile endospores. Product label claims of all nine disinfectants, except for product G, were verified against FCV (12). Product G did not show efficacy against either of the two HuNoV surrogates, presumably due to differences in test conditions (inoculum volume and drying time) recommended by the EPA and ASTM testing methods (18-20). Viruses were shown to be more susceptible to disinfectants in suspension than when dried on carriers (27). A likely explanation for this observation is that the differences in inoculum volume and drying time between the two methods lead to differences in virus susceptibility to disinfectants.

Neutralizing the disinfectants after the specified contact time with the viruses is critical to eliminate potential cytotoxicity when using cell culture to measure reduction of viral infectivity. Cell death caused by potential cytotoxicity of disinfectants cannot be distinguished from the cytopathic effect caused by viral infectivity, and thus strong cytotoxicity can result in difficulties to estimate product efficacy (28). Our testing protocol which includes "washing steps" was designed to minimize the cytotoxicity of the disinfectants. In addition, concentrating disinfectant-treated viruses by ultrafiltration has been shown to maintain infectivity of SARSCoV-2, suggesting that our testing method was more conservative than the EPA method using glass carriers (29).

Chlorine-based disinfectants have been reported to show efficacy against $C$. difficile spores due to their oxidation activity while QACs and alcohols are ineffective against HuNoV and bacterial spores in several studies $(8,17,30)$. Of the products studied in this analysis, only product $D$, a $\mathrm{H}_{2} \mathrm{O}_{2}$-based product, had a claim against both HuNoV and $C$. difficile spores. Other $\mathrm{H}_{2} \mathrm{O}_{2}$-based products among the 9 disinfectants studied, showed efficacy against both FCV and TuV and $C$. difficile spores in a suspension test, and two products $(A$ and $D)$ presented strong antimicrobial activities with small D-values $(<1 \mathrm{~min})$ against $C$. difficile spores. However, only product D showed efficacy on a stainless-steel carrier, while disinfectants based on other active ingredients (i.e., QACs and alcohols) were not efficacious against $C$. difficile spores. As a bacterial spore is a dormant structure, alcohols and QACs present limited impacts on the surface of the structure (31). On the other hand, the production of superoxide ions and free radicals from $\mathrm{H}_{2} \mathrm{O}_{2}$, such as 
hydroxyl radicals, was reported to be toxic against some bacterial spores and viral particles (32) with one study reporting the efficacy of $\mathrm{H}_{2} \mathrm{O}_{2}$-based surface disinfectants against HuNoV (33).

Unexpectedly, no strong correlation was found between concentration of $\mathrm{H}_{2} \mathrm{O}_{2}$-based disinfectants and $\log$ reduction. Specifically, the D-values ( $>5 \mathrm{~min}$ ) of two $\mathrm{H}_{2} \mathrm{O}_{2}$-based products ( $\mathrm{C}$ and $\mathrm{E}$ ), which contained even higher concentrations of $\mathrm{H}_{2} \mathrm{O}_{2}$ than products $A$ and $D$, were found impractical for daily use of these disinfectants. These higher $\mathrm{D}$-values may be explained by the interactions between active ingredients and inert ingredients (17), which are often added to disinfectants for various reasons, such as improved cleaning performance, aesthetics, formulation stability, and hard water tolerance (34). In addition to $\mathrm{H}_{2} \mathrm{O}_{2}$, accelerated hydrogen peroxide contains stabilizers, surfactants and other inert ingredients, which act synergistically to yield an effective disinfectant (35-38). For example, $\mathrm{H}_{2} \mathrm{O}_{2}$ is commonly stabilized by organic ligands (e.g., citric acid and malonic acid) to prevent self-degradation (35), and adding ferrous ions to a $\mathrm{H}_{2} \mathrm{O}_{2}$ solution, known as Fenton reaction, enhances $\mathrm{H}_{2} \mathrm{O}_{2}$ reactivity (39-43). Production of hydroxyl radicals and hydroperoxyl radicals during the Fenton reaction is believed to cause cytotoxicity leading to DNA damage and protein denaturation $(42,43)$. In our study, the inclusion of ferrous ions increased the efficacy of $1 \%$ stabilized $\mathrm{H}_{2} \mathrm{O}_{2}$ solution and resulted in an additional reduction of $\mathrm{FCV}$, TuV, and $C$. difficile spores $(42,43)$.

In agreement with a previous study (17), TuV was more resistant to acids than FCV likely due to differences in their viral capsid structures (44). Preserving amino acid residue G329 of the S-P1 hinge region of FCV is critical to maintain its infectivity (45). However, TuV has an isoleucine residue instead of glycine at this position, which is less impacted by oxidation $(46,47)$. In addition, the structure of TuV virion is more similar to HuNoV than other genera in the family Caliciviridae (46). Furthermore, like HuNoV, TuV utilizes histo-blood group antigens as binding ligands to infect cells. Thus, TuV rather than FCV should be considered as an appropriate surrogate for HuNoV disinfection studies.

Because HuNoV and $C$. difficile outbreaks in healthcare settings have been attributed to contamination of both hard and soft surfaces $(5,48), \mathrm{H}_{2} \mathrm{O}_{2}$-based disinfectants could be used as an alternative to chlorinebased products. The differences in the efficacy claims by the manufacturers and our data likely can be explained by the use of different testing methods. Though we conservatively estimated the efficacy of commercially available disinfectants on stainless steel carriers, the efficacy on other surfaces needs to be validated. Although TuV was confirmed as a more conservative surrogate for HuNoV than FCV, ultimately our findings should be validated using the recently reported human intestinal enteroid system for HuNoV (49).

\section{Conclusions}

Overall, $\mathrm{H}_{2} \mathrm{O}_{2}$-based disinfectants were found suitable as alternatives of chlorine-based disinfectants with efficacy against both HuNoV and $C$. difficile spores. Meanwhile, formula of disinfectants was proved as essential as active ingredients concentration. Although efficacy data were collected from a more conservative surrogate and testing method than EPA's requirements, disinfectants should be tested on other surfaces, and validated by human intestinal enteroid system for HuNoV for more widely use in the future. 


\section{Abbreviations}

ASTM: American Society for Testing and Materials; CDC: United States Centers for Diseases Control and Prevention; CRFK: Crandell-Rees Feline Kidney; EPA: United States Environmental Protection Agency; FCV: Feline calicivirus; HAls: Healthcare-associated infections; HuNoV: Human norovirus; MEM: Minimum Essential Medium; PBS: Buffered-saline solution; QAC: Quaternary ammonium compound; TuV: Tulane virus.

\section{Declarations}

\section{Ethics approval and consent to participate}

Not applicable.

\section{Consent for publication}

Not applicable.

\section{Availability of data and materials}

All data generated during this study are included in the published article.

\section{Competing interests}

The authors declare that they have no competing interests.

\section{Funding}

This research was financially supported by a grant from the Agency for Healthcare Research and Quality (AHRQ), Grant Number 1R01HS025987-01.

\section{Authors' contributions}

All authors contributed to the manuscript according to the ICMJE [International Committee of Medical Journal Editors] recommendations: JH and GWP were responsible for data acquisition. All authors were involved in analysis and interpretations of the data. JH and GWP prepared the manuscript. All authors critically revised the manuscript and are accountable for accuracy and correctness. All authors have read and agreed to the final draft before submission.

\section{Acknowledgement}

Any opinions, findings, conclusions, or recommendations expressed in this publication are those of the author(s) and do not necessarily reflect the view of the AHRQ. The findings and conclusions in this article are those of the authors and do not necessarily represent the official position of the Centers for Disease Control and Prevention.

\section{References}


1. Jump RLP, Crnich CJ, Mody L, Bradley SF, Nicolle LE, Yoshikawa TT. Infectious diseases in older adults of long-term care facilities: update on approach to diagnosis and management. J Am Geriatr Soc. 2018;66:789-803.

2. Steele MK, Wikswo ME, Hall AJ, Koelle K, Handel A, Levy K, Waller LA, Lopman BA. Characterizing norovirus transmission from outbreak data, United States. Emerg Infect Dis. 2020;26:1818-1825.

3. Guh AY, Mu Y, Winston LG, Johnston H, Olson D, Farley MM, Wilson LE, Holzbauer SM, Phipps EC, Dumyati GK, Beldavs ZG. Trends in US burden of Clostridioides difficile infection and outcomes. N Engl J Med. 2020;382(14):1320-30.

4. Riggs MM, Sethi AK, Zabarsky TF, Eckstein EC, Jump RL, Donskey CJ. Asymptomatic carriers are a potential source for transmission of epidemic and nonepidemic Clostridium difficile strains among long-term care facility residents. Clin Infect Dis. 2007;45:992-8.

5. Wu HM, Fornek M, Schwab KJ, Chapin AR, Gibson K, Schwab E, Spencer C, Henning K. A norovirus outbreak at a long-term-care facility: the role of environmental surface contamination. Infect Control Hosp Epidemiol. 2005;26:802-10.

6. Lopman B, Gastanaduy P, Park GW, Hall AJ, Parashar UD, Vinje J. Environmental transmission of norovirus gastroenteritis. Curr Opin Virol. 2012;2:96-102.

7. Centers for Disease Control and Prevention (CDC). Guidelines for environmental infection control in health-care facilities: recommendations of $\mathrm{CDC}$ and the Healthcare Infection Control Practices Advisory Committee (HICPAC). MMWR Recomm Rep. 2003;52:1-48. Accessed on July 2019.

8. Boyce JM. A review of wipes used to disinfect hard surfaces in healthcare facilities. Am J Infect Control. 2021;49:104-114.

9. Tyan K, Jin K, Kang J. Novel colour additive for bleach disinfectant wipes reduces corrosive damage on stainless steel. J Hosp Infect. 2019;103:227-230.

10. Luijkx G, Hild R, Krijnen E, Lodewick R, Rechenbach T, Reinhardt G. Testing of the fabric damage properties of bleach containing detergents. Tenside Surfactants Detergents. 2004;41:164-168.

11. Environmental Protection Agency. Selected EPA-registered disinfectants. Environmental Protection Agency. 2020. https://www.epa.gov/pesticide-registration/selected-epa-registered-disinfectants. Accessed on 12 Jun 2021.

12. Environmental Protection Agency. List G: EPA's registered antimicrobial products effective against norovirus. Environmental Protection Agency. 2020. https://www.epa.gov/pesticide-registration/list-g-epasregistered-antimicrobial-products-effective-against-norovirus. Accessed on 21 Feb 2021.

13. Environmental Protection Agency. List K: EPA's registered antimicrobial products effective against Clostridium difficile spores. Environmental Protection Agency. 2020. https://www.epa.gov/pesticide- 
registration/list-k-epas-registered-antimicrobial-products-effective-against-clostridium. Accessed on 21 Feb 2021.

14. Environmental Protection Agency. Disinfectants for use on environmental surfaces, guidance for efficacy testing. Environmental Protection Agency. 2018. https://www.regulations.gov/document/EPA-HQOPPT-2009-0150-0036. Accessed on 21 Feb 2021.

15. Environmental Protection Agency. Methods and guidance for testing the efficacy of antimicrobial products against spores of Clostridium difficile on hard non-porous surfaces. Environmental Protection Agency. 2018. https://www.epa.gov/pesticide-registration/methods-and-guidance-testing-efficacyantimicrobial-products-against-spores. Accessed on 21 Feb 2021.

16. Park GW, Barclay L, Macinga D, Charbonneau D, Pettigrew CA, Vinje J. Comparative efficacy of seven hand sanitizers against murine norovirus, feline calicivirus, and GII.4 norovirus. J Food Prot. 2010;73:22322238 .

17. Cromeans T, Park GW, Costantini V, Lee D, Wang Q, Farkas T, Lee A, Vinje J. Comprehensive comparison of cultivable norovirus surrogates in response to different inactivation and disinfection treatments. Appl Environ Microbiol. 2014;80:5743-5751.

18. Environmental Protection Agency. Initial virucidal effectiveness test. Environmental Protection Agency. 2000. https://www.epa.gov/sites/production/files/2015-09/documents/fcv1_initial_surf_pcol.pdf. Accessed on 21 Feb 2021.

19. Environmental Protection Agency. Confirmatory virucidal effictiveness test. Environmental Protection Agency. 2000. https://www.epa.gov/sites/production/files/2015-09/documents/fcv2_confirm_surf_pcol.pdf. Accessed on 21 Feb 2021.

20. ASTM International. E2197-17 Standard quantitative disk carrier test method for determining bactericidal, virucidal, fungicidal, mycobactericidal, and sporicidal activities of chemicals. 2017. doi:https://doi.org/10.1520/E2197-17. ASTM International, West Conshohocken, PA.

21. Cheng VCC, Chau PH, Lee WM, Ho SKY, Lee DWY, So SYC, Tai JWM, Yuen KY. Hand-touch contact assessment of high-touch and mutual-touch surfaces among healthcare workers, patients, and visitors. J. Hosp. Infect. 2015;90(3):220-225.

22. Kundrapu S, Sunkesula V, Jury LA, Sitzlar BM, Donskey CJ. Daily disinfection of high-touch surfaces in isolation rooms to reduce contamination of healthcare workers' hands. Infect Control Hosp Epidemiol. 2012;33(10):1039-1042.

23. Buckley D, Dharmasena M, Fraser A, Pettigrew C, Anderson J, Jiang X. Efficacy of silver dihydrogen citrate and steam vapor against a human norovirus surrogate, feline calicivirus, in suspension, on glass, and on carpet. Appl Environ Microbiol. 2018;84:e00233-18. 
24. Tian P, Yang D, Quigley C, Chou M, Jiang X. Inactivation of the Tulane virus, a novel surrogate for the human norovirus. J Food Prot. 2013;76:712-718.

25. Edwards AN, McBride SM. Isolating and purifying Clostridium difficile spores. Methods Mol Biol. 2016;1476:117-128.

26. ASTM International. E1052-11 Standard test method to assess the activity of microbicides against viruses in suspension. 2011. doi:https://doi.org/10.1520/E1052-11. ASTM International, West Conshohocken, PA.

27. Park GW, Boston DM, Kase JA, Sampson MN, Sobsey MD. Evaluation of liquid- and fog-based application of Sterilox hypochlorous acid solution for surface inactivation of human norovirus. Appl Environ Microbiol. 2007;73:4463-4468.

28. Geller C, Fontanay S, Finance C, Duval RE. A new Sephadex-based method for removing microbicidal and cytotoxic residues when testing antiseptics against viruses: experiments with a human coronavirus as a model. J Virol Methods. 2009;159:217-226.

29. Welch SR, Davies KA, Buczkowski H, Hettiarachchi N, Green N, Arnold U, Jones M, Hannah MJ, Evans R, Burton C, Burton JE, Guiver M, Cane PA, Woodford N, Bruce CB, Roberts ADG, Killip MJ. Analysis of inactivation of SARS-CoV-2 by specimen transport media, nucleic acid extraction reagents, detergents, and fixatives. J Clin Microbiol. 2020;58(11):e01713-20.

30. Ha JH, Choi C, Lee HJ, Ju IS, Lee JS, Ha SD. Efficacy of chemical disinfectant compounds against human norovirus. Food Control. 2016;59:524-529.

31. Russell AD. Mechanisms of bacterial insusceptibility to biocides. Am J Infect Control. 2001;29(4):259261.

32. Sugiura Y, Suzuki T, Kuwahara J, Tanaka H. On the mechanism of hydrogen peroxide-, superoxide-, and ultraviolet light-induced DNA cleavages of inactive bleomycin-iron (III) complex. Biochem Biophys Res Commun. 1982;105:1511-1518.

33. Linley E, Denyer SP, McDonnell G, Simons C, Maillard JY. Use of hydrogen peroxide as a biocide: new consideration of its mechanisms of biocidal action. J Antimicrob Chemoth. 2012;67:1589-1596.

34. Fraser AM, Anderson J, Goncalves J, Black E, Starobin A, Buckley D, Grinstead D, Manuel C, Hollingsworth, J. Sanitizers and disinfectants: a retail food and foodservice perspective. Food Prot Trends. 2021;41(3):358-367.

35. Watts RJ, Finn DD, Cutler LM, Schmidt JT, Teel AL. Enhanced stability of hydrogen peroxide in the presence of subsurface solids. J Contam Hydrol. 2007;91:312-326.

36. Ramirez JA, Rochon MJ. Hydrogen peroxide disinfectant with increased activity. 2004. US patent $6,803,057$. 
37. Grascha P, Battut M. Chemical composition with hydrogen peroxide and a nanoemulsion of longchained alcohols. 2014. US patent 9,844,216.

38. Ramirez JA, Omidbakhsh, N. Enhanced activity hydrogen peroxide disinfectant. 2014. US patent $8,637,085$.

39. Hayyan M, Hashim MA, AINashef IM. Superoxide ion: generation and chemical implications. Chemical reviews. 2016;116:3029-3085.

40. Polo D, García-Fernández I, Fernández-lbañez P, Romalde JL. Hepatitis A virus disinfection in water by solar photo-Fenton systems. Food and Environ Virol. 2018;10:159-166.

41. Cross JB, Currier RP, Torraco DJ, Vanderberg LA, Wagner GL, Gladen PD. Killing of Bacillus spores by aqueous dissolved oxygen, ascorbic acid, and copper ions. Appl Environ Microbiol. 2003;69(4):2245-2252.

42. Tong M, Liu F, Dong Q, Ma Z, Liu W. Magnetic $\mathrm{Fe}_{3} \mathrm{O}_{4}$-deposited flower-like $\mathrm{MoS}_{2}$ nanocomposites for the Fenton-like Escherichia coli disinfection and diclofenac degradation. J Hazard Mater. 2020;385:121604.

43. Nieto-Juarez Jl, Pierzchla K, Sienkiewicz A, Kohn T. Inactivation of MS2 coliphage in Fenton and Fenton-like systems: role of transition metals, hydrogen peroxide and sunlight. Environ Sci Technol. 2010;44:3351-3356.

44. Bailey D, Thackray LB, Goodfellow IG. A single amino acid substitution in the murine norovirus capsid protein is sufficient for attenuation in vivo. J Virol. 2008;82(15):7725-7728.

45. Ossiboff RJ, Zhou Y, Lightfoot PJ, Prasad BVV, Parker JSL. Conformational changes in the capsid of a calicivirus upon interaction with its functional receptor. J Virol. 2010;84:5550-5564.

46. Yu GM, Zhang DS, Guo F, Tan M, Jiang X, Jiang W. Cryo-EM structure of a novel calicivirus, Tulane virus. Plos One. 2013;8:e59817.

47. Dean RT, Fu SL, Stocker R, Davies MJ. Biochemistry and pathology of radical-mediated protein oxidation. Biochem J. 1997;324:1-18.

48. Dubberke ER, Reske KA, Noble-Wang J, Thompson A, Killgore G, Mayfield J, Camins B, Woeltje K, McDonald JR, McDonald LC, Fraser VJ. Prevalence of Clostridium difficile environmental contamination and strain variability in multiple health care facilities. Am J Infect Control. 2007;35:315-318.

49 Costantini V, Morantz EK, Browne H, Ettayebi K, Zeng XL, Atmar RL, Estes MK, Vinjé J. Human Norovirus Replication in Human Intestinal Enteroids as Model to Evaluate Virus Inactivation. Emerg Infect Dis. 2018;24(8):1453-1464.

\section{Figures}




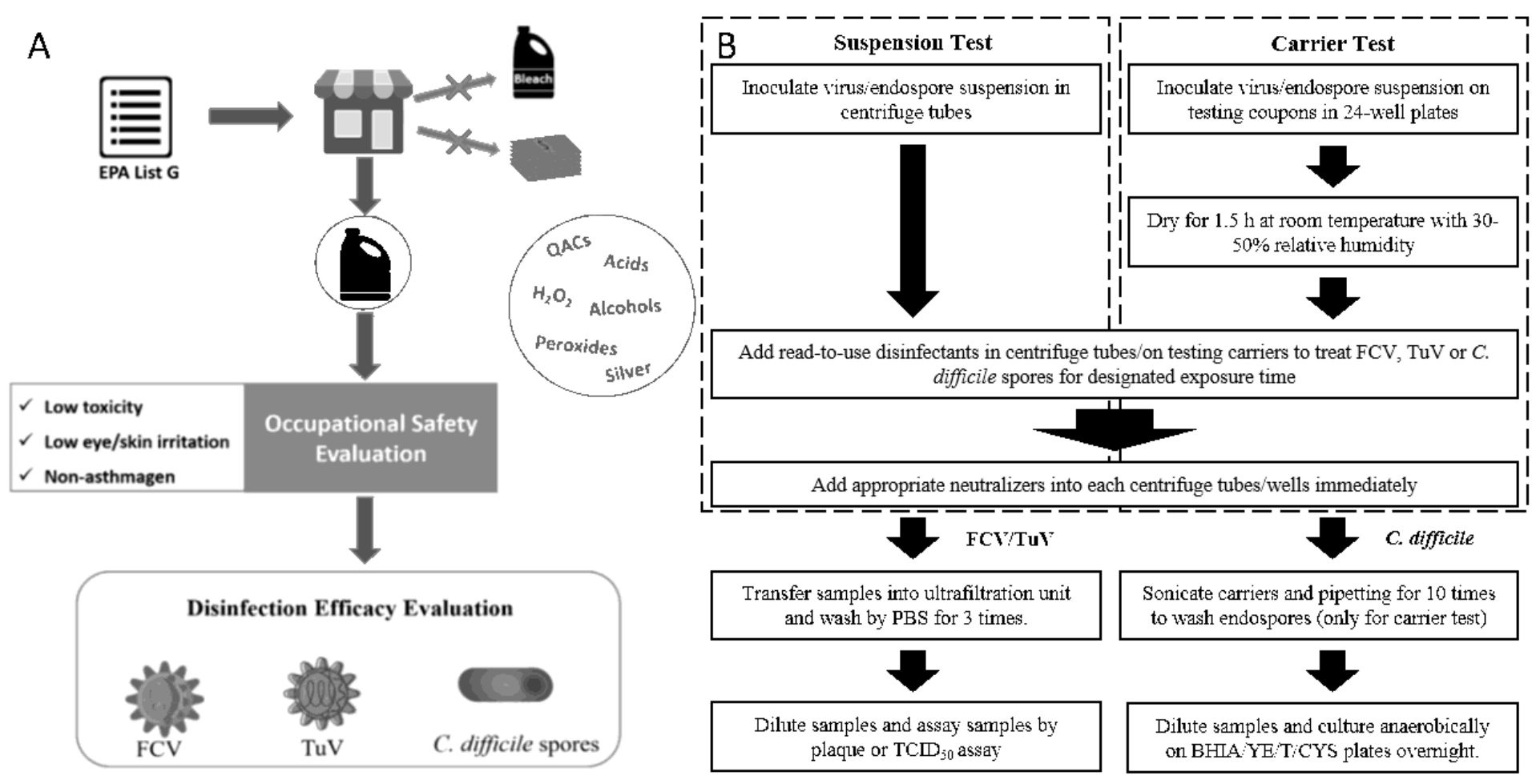

\section{Figure 1}

Selection criteria of disinfectants (A), and workflow for suspension test and carrier test (B). 


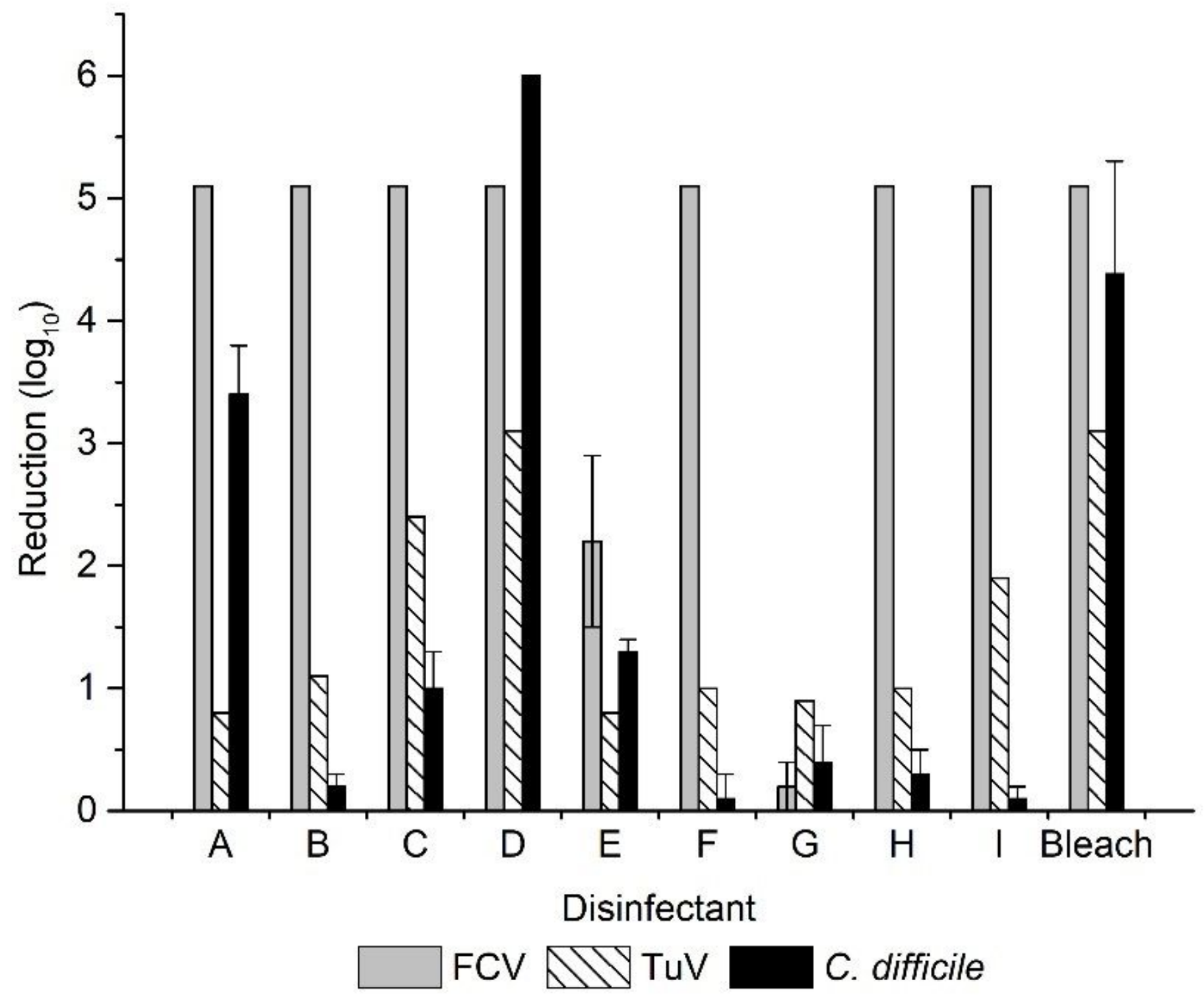

Figure 2

Efficacy of nine commercially available disinfectants and bleach $(1,000 \mathrm{ppm})$ against FCV, TuV and C. difficile spores on stainless steel carriers. Contact time for FCV, TuV and C. difficile spores was 5, 5 and 10 min, respectively. Error bars represent standard deviations from replicates in two independent experiments. 


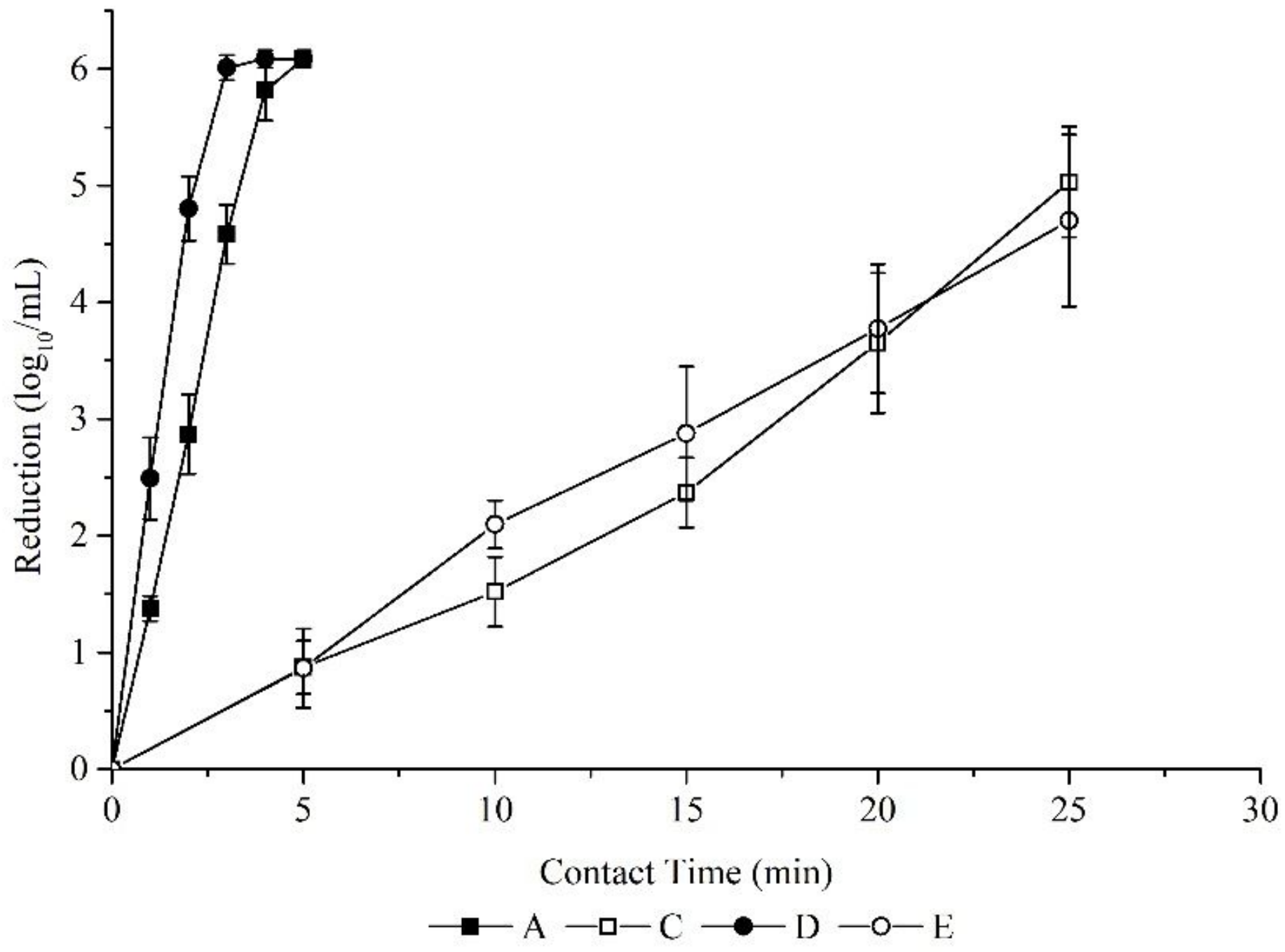

Figure 3

Inactivation curves of products A ( $\square), C(\square), D(\bullet)$ and $E(\bullet)$ against C. difficile spores in suspension. Error bars represent standard deviations from replicates in two independent experiments. 

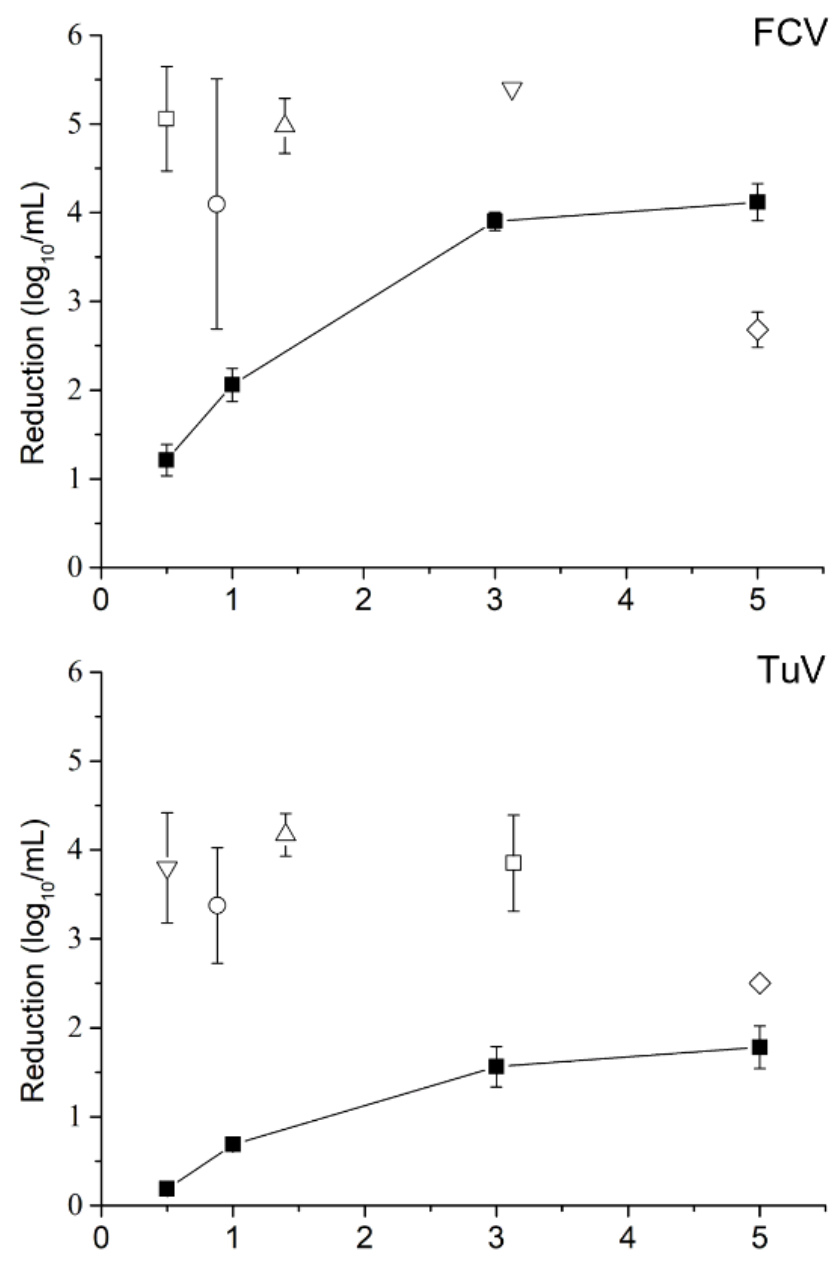

Product (symbol) $/ \mathrm{H}_{2} \mathrm{O}_{2} \%$
$\mathrm{A}(\nabla) / 0.5 \%$
$\mathrm{B}(0) / 0.88 \%$
$\mathrm{C}(\triangle) / 1.4 \%$
$\mathrm{D}$ (ㅁ) $/ 3.13 \%$
$E(\diamond) / 5 \%$

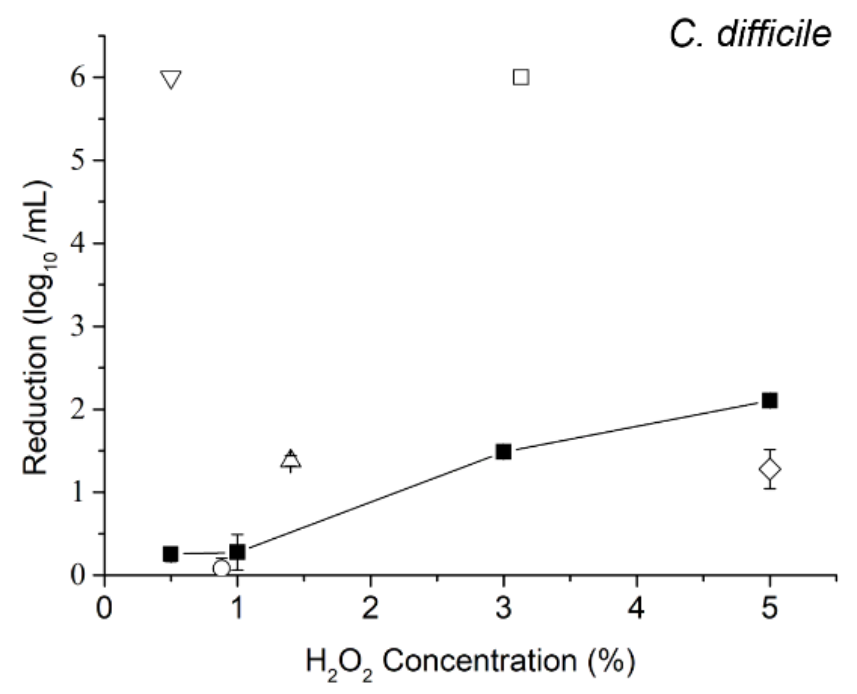

Figure 4

Efficacy of $\mathrm{H} 2 \mathrm{O} 2$ against FCV, TuV and C. difficile spores at contact times of 1,10 and 10 min, respectively. Solid squares indicate efficacy of $\mathrm{H} 2 \mathrm{O} 2$ solutions at various concentrations ( $0.5,1,3$ and $5 \%)$, and open symbols indicate inactivation efficacy of 5 commercial H2O2-based disinfectants (A, B, C, D and E). Error bars represent standard deviation from replicates in two independent experiments. 


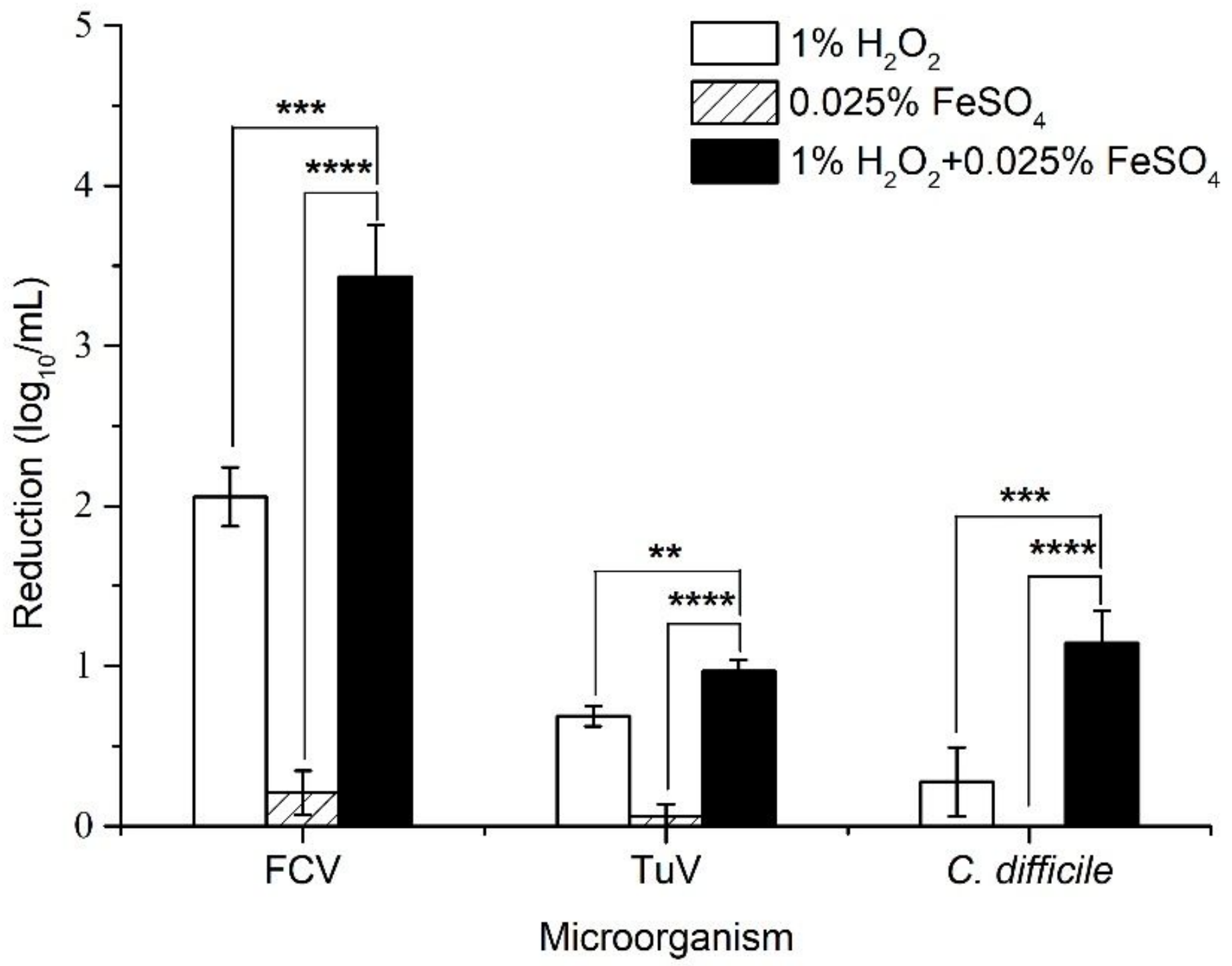

Figure 5

Efficacy of $\mathrm{H} 2 \mathrm{O} 2$ against FCV, TuV and C. difficile spores as affected by ferrous sulfate. White bars indicate efficacy of $1 \% \mathrm{H} 2 \mathrm{O} 2$, bars with slash pattern indicate efficacy of $0.025 \%$ FeSO4, and black bars indicate efficacy of $1 \% \mathrm{H} 2 \mathrm{O} 2+0.025 \%$ FeSO 4 . The contact times for FCV, TuV and C. difficile spores were 1, 10 and $10 \mathrm{~min}$, respectively. Error bars represent standard deviations from replicates in two independent experiments. The p-value among treatments for each microorganism was $\leq 0.01(* \star), \leq 0.001(\star \star \star)$ and $\leq 0.0001{ }^{(* \star \star *)}$, respectively.

\section{Supplementary Files}

This is a list of supplementary files associated with this preprint. Click to download.

- ARICDannyHSupplementaryData.docx 